\title{
The effect of dietary bee pollen intake on growth performance and biochemical indicators of rats
}

\author{
Branislav Gálik ${ }^{1}$, Daniel Bíro ${ }^{1}$, Milan Šimko ${ }^{1}$, Miroslav Juráček ${ }^{1}$, Marcela Capcarová2, \\ Adriana Kolesárová ${ }^{2}$, Michal Rolinec ${ }^{1}$, Róbert Toman ${ }^{3}$, Tomáš Kanka ${ }^{3}$ \\ Slovak University of Agriculture in Nitra, \\ ${ }^{1}$ Faculty of Agrobiology and Food Resources, Department of Animal Nutrition, \\ ${ }^{2}$ Faculty of Biotechnology and Food Sciences, Department of Animal Physiology, \\ ${ }^{3}$ Faculty of Agrobiology and Food Resources, Department of Veterinary Disciplines, \\ Nitra, Slovak Republic \\ Received June 3, 2015 \\ Accepted February 10, 2016
}

\begin{abstract}
The aim of this study was to analyse the effects of different daily intakes of rapeseed bee pollen on the growth and biochemical blood serum indicators in male and female rats. A total of 40 clinically healthy male and female Wistar rats were randomly divided into four groups. In the control group (C) rats were fed a standard complete diet; in the experimental groups standard diets were supplemented with different doses of bee pollen. Treatment group T1 was given standard diet with the addition of bee pollen at a $0.3 \%$ concentration; in group T2 the addition was $0.5 \%$; and in group T3 it was $0.75 \%$. The experimental period lasted for 90 days. A significant effect $(P<0.05)$ of bee pollen on the body weight gain and feed conversion ratio of female rats was found. Significantly $(P<0.05)$ higher cholesterol concentration in blood serum of male rats was found in the groups with bee pollen addition (groups T2 and T3) compared to the control group. Lower triglyceride serum content in all female experimental groups (T1 and T3) was observed in comparison to the control. Higher serum cholesterol content in the experimental female rats was detected; significant differences were analysed in groups T1 and T3 compared to the control female group. Rapeseed bee pollen at concentrations of 0.5 and $0.75 \%$ positively affected the body weight gain of female rats, however, with higher feed consumption $(P<0.05)$. Rapeseed bee pollen reduced the triglycerides serum content in female rats and increased the cholesterol serum content in male and female rats $(P<0.05)$.
\end{abstract}

Additives, efficiency, blood serum, model animals

Phytogenic feed additives may be included among supplements that are aimed to positively affect feed quality, health of animals as well as animal products by means of their specifically efficacious substances (Karásková et al. 2015). Bee pollen is an agglomerate of flower pollen collected by the bees and mixed with nectar and secretions from the hypopharyngeal glands (Carpes et al. 2009). Bee pollen is rich in many nutrients, minerals, and enzymes (Zuo and Xu 2003; Bíro et al. 2010, Kňazovická et al. 2011). For animals, bee pollen can be used as a potential growth promotor (Šarič et al. 2009). Bee pollen has been shown to stimulate the growth performance and feed intake in rabbits and can be beneficial in feed conversion ratio (Attia et al. 2011a). The aim of this study was to analyse the effect of the dietary addition of rape seed bee pollen of different percentages on the growth intensity and biochemical serum variables in male and female rats.

\section{Materials and Methods}

Animals, feeding and housing

A total of 40 clinically healthy male and female Wistar rats (Slovak University of Agriculture in Nitra, Slovak Republic) were divided randomly into four groups ( 5 male and 5 female rats per group). All rats were 40 days old; the mean body weights of male and female rats were $168.0 \pm 10.5 \mathrm{~g}$ and $129.0 \pm 11.0 \mathrm{~g}$, respectively (at the age 
40 days). The rats were individually housed in plastic cages (Tecniplast, Varese, Italy) in the accredited laboratory (SK PC 50004) of the Slovak University of Agriculture in Nitra (Slovak Republic) under standard conditions (temperature $20-24{ }^{\circ} \mathrm{C}, 55 \pm 10 \%$ of humidity and $12 \mathrm{~h} / 12 \mathrm{~h}$ of light/dark regime). Feed and water were supplied ad libitum. The experiment lasted for 90 days. The rats were fed a complete granular diet (control group), or a complete granular diet supplemented with dried rapeseed bee pollen at the dose of $3 \mathrm{~kg}$ per $1,000 \mathrm{~kg}$ of feed (treatment group T1), $5 \mathrm{~kg}$ per 1,000 kg of feed (treatment group T2) or $7.5 \mathrm{~kg}$ per 1,000 g of feed (treatment group T3). Bee pollen collected by pollen traps was obtained from local bee keepers of the western region of the Slovak Republic. Feed consumption and body weight gains were recorded individually and weekly. Nutrient contents in the complete granular diet and in bee pollen are shown in Table 1. The experiment was approved by the local Ethics Committee and the State Veterinary and Food Administration of the Slovak Republic (reg. no. 2072/08-221/3)

Table 1. Nutrient composition of the complete diet and bee pollen.

\begin{tabular}{lllllrrr}
\hline & $\mathrm{DM}$ & $\mathrm{CP}$ & $\mathrm{CF}$ & $\mathrm{F}$ & $\mathrm{OM}$ & $\mathrm{Ca}$ & $\mathrm{P}$ \\
\cline { 2 - 8 } & $\mathrm{g} \cdot \mathrm{kg}^{-1}$ & & \multicolumn{7}{c}{$\mathrm{g} \cdot \mathrm{kg}^{-1}$ of dry matter } & \\
\hline CD & 914.3 & 233.9 & 27.3 & 26.5 & 933.2 & 12.1 & 5.5 \\
Bee pollen & 856.3 & 190.9 & 29.5 & 13.4 & 429.2 & 1.8 & 5.3 \\
\hline
\end{tabular}

CD - complete diet; DM - dry matter; CP - crude protein; CF - crude fat; F - crude fibre; OM - organic matter; $\mathrm{Ca}$ - calcium; P - phosphorus

Blood sampling and analyses

Blood samples were collected after the rats were killed by decapitation following anaesthesia with ether. Blood samples were centrifuged for $30 \mathrm{~min}$ at $3000 \times \mathrm{g}$ and blood serum was obtained. In the serum biochemical indicators as triglycerides, cholesterol, glucose, total proteins, total creatinine, urea, aspartate aminotransferase (AST), alanine aminotransferase (ALT), and alkaline phosphatase (ALP) using Ecoline kits on automatic analyser Microlab 300 $\left(\right.$ Merck $^{\circledR}$, Germany), spectrophotometer Genesys 10 (Thermo Fisher Scientific Inc., USA) and microprocessorcontrolled analyser EasyLite (Medica, Bedford, USA) according to manufacturer conditions were analysed.

\section{Statistical analysis}

The data used for statistical analyses represent means of values obtained from 10 animals ( 5 males and 5 females) from each group. To calculate basic statistic characteristics, to determine significance of differences, and to compare results one-way ANOVA and Student's $t$-test were performed at a value of $P<0.05$. The SAS statistical package was used (SAS Inc., New York City, USA).

\section{Results}

The effect of different doses of rapeseed bee pollen added to the feed on the body weight and feed consumption was tested. The results are shown in Table 2 . Non-significant $(P>0.05)$ effects of rapeseed bee pollen were found. The highest body weight of male and

Table 2. Body weight development of rats (mean \pm S.D.).

\begin{tabular}{|c|c|c|c|c|}
\hline \multirow{3}{*}{ Group } & $\mathrm{BW}^{1}$ & $\mathrm{BW}^{2}$ & $\mathrm{BW}^{1}$ & $\mathrm{BW}^{2}$ \\
\hline & \multirow{2}{*}{\multicolumn{2}{|c|}{$\begin{array}{c}\mathrm{kg} \\
\text { Male }(\mathrm{n}=5)\end{array}$}} & \multirow{2}{*}{\multicolumn{2}{|c|}{$\begin{array}{c}\mathrm{kg} \\
\text { Female }(\mathrm{n}=5)\end{array}$}} \\
\hline & & & & \\
\hline $\mathrm{C}$ & $161 \pm 13.42$ & $371 \pm 11.40$ & $122 \pm 4.47$ & $247 \pm 15.65$ \\
\hline $\mathrm{T} 1$ & $158 \pm 8.37$ & $368 \pm 25.15$ & $118 \pm 8.37$ & $244 \pm 14.48$ \\
\hline $\mathrm{T} 2$ & $179 \pm 11.40$ & $381 \pm 19.50$ & $138 \pm 12.72$ & $238 \pm 19.24$ \\
\hline $\mathrm{T} 3$ & $158 \pm 17.35$ & $388 \pm 52.52$ & $140 \pm 12.75$ & $388 \pm 52.52$ \\
\hline
\end{tabular}

$\mathrm{BW}^{1}$ - body weight at the beginning of experiment (40-day-old rats); $\mathrm{BW}^{2}$ - body weight at the end of experiment (130-day-old rats); C - control group; T1 - group with $0.3 \%$ of bee pollen in diet; T2 - group with $0.5 \%$ of bee pollen in diet; T3 - group with $0.75 \%$ of bee pollen in diet. 
female rats after 90 days of bee pollen intake was detected in the group with the highest bee pollen concentration in the diet (group T3).

Table 3. Body weight gain and feed conversion ratio of rats (mean \pm S.D.).

\begin{tabular}{|c|c|c|c|c|}
\hline \multirow{2}{*}{ Group } & $\mathrm{BW}^{1}$ & $\mathrm{BW}^{2}$ & $\mathrm{BW}^{1}$ & $\mathrm{BW}^{2}$ \\
\hline & \multicolumn{2}{|c|}{$\begin{array}{c}\mathrm{g} \\
\text { Male }(\mathrm{n}=5)\end{array}$} & \multicolumn{2}{|c|}{$\begin{array}{c}\mathrm{g} \\
\text { Female }(\mathrm{n}=5)\end{array}$} \\
\hline $\mathrm{C}$ & $0.211 \pm 14.32$ & $6.11 \pm 0.31$ & $0.125 \pm 12.25^{\mathrm{ab}}$ & $6.82 \pm 0.59^{\mathrm{ab}}$ \\
\hline $\mathrm{T} 1$ & $0.190 \pm 25.14$ & $6.14 \pm 0.52$ & $0.126 \pm 8.22$ & $6.60 \pm 0.50$ \\
\hline $\mathrm{T} 2$ & $0.202 \pm 10.37$ & $6.40 \pm 0.40$ & $0.99 \pm 9.12^{\mathrm{a}}$ & $8.27 \pm 0.70^{\mathrm{a}}$ \\
\hline $\mathrm{T} 3$ & $0.231 \pm 22.73$ & $5.54 \pm 0.62$ & $0.248 \pm 55.30^{\mathrm{b}}$ & $7.77 \pm 0.93^{b}$ \\
\hline
\end{tabular}

BWG - body weight gain; FCR - feed conversion ratio; C - control group; T1 - group with $0.3 \%$ of bee pollen in diet; T2 - group with $0.5 \%$ of bee pollen in diet; T3 - group with $0.75 \%$ of bee pollen in diet. Values with identical superscript are significantly different at the level of 0.05 .

Results of the effect of rapeseed bee pollen on the body weight gain and feed conversion ratio are shown in Table 3. The highest body weight gain of male rats was found in group $\mathrm{T} 3(0.231 \mathrm{~kg})$, as was also the lowest feed conversion ratio $(5.54 \mathrm{~kg})$. Similar results were measured for the body weight gain in females. The highest body weight gain was found in group T3 and the difference was significant $(P<0.05)$ compared to the control group and to group T2. The feed conversion ratio in male group T3 was significantly $(P<0.05)$ higher than in the control group, and significantly $(P<0.05)$ lower than in group T2. Tendency for the lowest feed conversion ratio $(P>0.05)$ was found in the group with the lowest bee pollen concentration in feed (group T1).

The effect of different doses of rapeseed bee pollen on biochemical indicators of male and female rat serum is shown in Table 4. For triglyceride (TRG) concentration in males

Table 4. Energy and protein blood profile of male and female rats fed a particular diet (mean \pm S.D.).

\begin{tabular}{|c|c|c|c|c|}
\hline \multirow{2}{*}{ Group } & $\mathrm{C}$ & $\mathrm{T} 1$ & $\mathrm{~T} 2$ & $\mathrm{~T} 3$ \\
\hline & \multicolumn{3}{|c|}{ Male $(\mathrm{n}=5)$} & \\
\hline TRG $\left(\mathrm{mmol} \cdot 1^{-1}\right)$ & $1.24 \pm 0.21$ & $0.89 \pm 1.23$ & $1.43 \pm 0.20$ & $0.72 \pm 0.08$ \\
\hline $\mathrm{CHOL}\left(\mathrm{mmol} \cdot 1^{-1}\right)$ & $1.29 \pm 0.18^{\mathrm{ab}}$ & $1.36 \pm 0.19$ & $1.64 \pm 0.14^{\mathrm{a}}$ & $1.80 \pm 0.23^{b}$ \\
\hline $\mathrm{GLU}\left(\mathrm{mmol} \cdot \mathrm{l}^{-1}\right)$ & $8.36 \pm 0.21$ & $9.52 \pm 1.14$ & $8.14 \pm 1.20$ & $7.28 \pm 0.83$ \\
\hline $\mathrm{TP}\left(\mathrm{g} \cdot \mathrm{1}^{-1}\right)$ & $79.18 \pm 1.81^{\mathrm{a}}$ & $72.81 \pm 4.20^{\mathrm{a}}$ & $81.20 \pm 3.86$ & $79.63 \pm 4.18$ \\
\hline $\mathrm{TC}\left(\mathrm{mmol} \cdot \mathrm{l}^{-1}\right)$ & $2.28 \pm 0.32$ & $2.32 \pm 0.26$ & $0.50 \pm 0.03$ & $2.39 \pm 0.26$ \\
\hline \multirow[t]{2}{*}{$\operatorname{UREA}\left(\mathrm{mmol} \cdot \mathrm{l}^{-1}\right)$} & $8.54 \pm 0.50$ & $8.46 \pm 1.02$ & $8.76 \pm 0.67$ & $8.08 \pm 1.07$ \\
\hline & \multicolumn{3}{|c|}{ Female $(\mathrm{n}=5)$} & \\
\hline TRG $\left(\mathrm{mmol} \cdot \mathrm{l}^{-1}\right)$ & $1.40 \pm 0.23^{\mathrm{ab}}$ & $1.05 \pm 0.06^{\mathrm{a}}$ & $1.18 \pm 0.11$ & $1.39 \pm 0.23^{b}$ \\
\hline $\mathrm{CHOL}\left(\mathrm{mmol} \cdot 1^{-1}\right)$ & $1.18 \pm 0.09^{\mathrm{ab}}$ & $1.50 \pm 0.23^{\mathrm{a}}$ & $1.24 \pm 0.09$ & $1.77 \pm 0.21^{\mathrm{b}}$ \\
\hline GLU $\left(\mathrm{mmol}^{-1} \mathrm{l}^{-1}\right)$ & $7.86 \pm 0.86$ & $8.08 \pm 0.78$ & $9.0 \pm 1.45$ & $7.5 \pm 0.94$ \\
\hline $\mathrm{TP}\left(\mathrm{g} \cdot \mathrm{l}^{-1}\right)$ & $72.48 \pm 3.63^{\mathrm{a}}$ & $71.64 \pm 4.12$ & $78.62 \pm 6.16$ & $83.49 \pm 2.09^{\mathrm{a}}$ \\
\hline $\mathrm{TC}\left(\mathrm{mmol} \cdot \mathrm{l}^{-1}\right)$ & $0.46 \pm 0.05$ & $1.33 \pm 0.07$ & $2.79 \pm 0.44$ & $0.87 \pm 0.09$ \\
\hline $\operatorname{UREA}\left(\mathrm{mmol} \cdot \mathrm{l}^{-1}\right)$ & $7.96 \pm 1.12^{\mathrm{a}}$ & $9.46 \pm 0.31^{\mathrm{a}}$ & $7.76 \pm 0.86$ & $8.32 \pm 0.86 \mathrm{~T}$ \\
\hline
\end{tabular}

RG - triglycerides; CHOL - cholesterol; GLU - glucose; TP - total protein; TC - total creatinine. Values with identical superscript are significantly different at the level of 0.05 . 
we did not find any significant effect of the tested additive between the groups. After bee pollen consumption at doses of $0.3 \%$ (group T1) and $0.75 \%$ (group T3), significantly $(P<0.05)$ higher TRG concentration was found in male rats compared to the control group. An increase of CHOL concentrations as an effect of a higher bee pollen intake was found. Serum cholesterol $(\mathrm{CHOL})$ of males was significantly $(P<0.05)$ affected at the doses of 0.5 and $0.75 \%$ of rapeseed bee pollen. Serum glucose content showed a dose-dependent decreasing tendency in the experimental groups; however, the results were non-significant $(P>0.05)$. Treatment with bee pollen had no influence $(P>0.05)$ on the remaining serum indicators, such as total proteins, total creatinine, and urea.

Dietary intake of rapeseed bee pollen had a positive effect on serum TRG concentration in female rats. In comparison with the control group, significantly lower $(P<0.05)$ content of TRG in groups T1 and T3 was found. Significantly higher $(P<0.05)$ serum CHOL concentrations was measured in female rats in groups fed with 0.3 or $0.75 \%$ of bee pollen concentrations in the diet compared to the control. A tendency $(P>0.05)$ for higher serum glucose (GLU) was analysed as an effect of bee pollen consumption. In serum TP concentrations, a tendency $(P>0.05)$ for higher concentrations was found in female rats. In TC and urea serum concentrations we found a non-significant $(P>0.05)$ effect of the intake of rapeseed bee pollen in female rats.

Enzymatic blood profile of rats fed a particular diet is shown in Table 5. In male rats, significant differences $(P<0.05)$ were found in ALT and ALP activities.

Table 5. Enzymatic blood profile of male and female rats fed a particular diet (mean \pm S.D.).

\begin{tabular}{|c|c|c|c|c|}
\hline \multirow[b]{2}{*}{ Group } & $\mathrm{C}$ & $\mathrm{T} 1$ & $\mathrm{~T} 2$ & $\mathrm{~T} 3$ \\
\hline & \multicolumn{4}{|c|}{ Male $(\mathrm{n}=5)$} \\
\hline $\operatorname{AST}\left(\mu \mathrm{kat} \cdot 1^{-1}\right)$ & $6.5 \pm 0.84$ & $5.51 \pm 0.39$ & $3.93 \pm 0.55$ & $4.29 \pm 0.43$ \\
\hline $\operatorname{ALT}\left(\mu \mathrm{kat} \cdot \mathrm{l}^{-1}\right)$ & $1.31 \pm 0.15^{\mathrm{a}}$ & $0.97 \pm 0.12^{\mathrm{a}}$ & $2.10 \pm 0.24$ & $1.31 \pm 0.18$ \\
\hline \multirow[t]{2}{*}{$\operatorname{ALP}\left(\mu \mathrm{kat} \cdot 1^{-1}\right)$} & $5.68 \pm 0.73^{\mathrm{a}}$ & $5.44 \pm 0.39$ & $5.08 \pm 0.69$ & $3.92 \pm 0.54^{\mathrm{a}}$ \\
\hline & \multicolumn{4}{|c|}{ Female $(\mathrm{n}=5)$} \\
\hline $\operatorname{AST}\left(\mu \mathrm{kat} \cdot 1^{-1}\right)$ & $8.45 \pm 0.92^{\mathrm{a}}$ & $6.58 \pm 1.11^{\mathrm{a}}$ & $3.72 \pm 0.51$ & $8.69 \pm 0.78$ \\
\hline $\operatorname{ALT}\left(\mu \mathrm{kat} \cdot 1^{-1}\right)$ & $1.32 \pm 0.33^{\mathrm{a}}$ & $1.13 \pm 0.19$ & $0.77 \pm 0.07^{\mathrm{a}}$ & $1.13 \pm 0.14$ \\
\hline $\operatorname{ALP}\left(\mu \mathrm{kat} \cdot 1^{-1}\right)$ & $3.87 \pm 0.37^{\mathrm{ab}}$ & $5.09 \pm 0.58^{\mathrm{a}}$ & $5.87 \pm 0.79$ & $2.98 \pm 0.39^{b}$ \\
\hline
\end{tabular}

AST - aspartate aminotransferase; ALT - alanine aminotransferase; ALP - alkaline phosphatase. Values with identical superscript are significantly different at the level of 0.05

In female rats we found a tendency $(P>0.05)$ for lower AST activity, except group T3. Significantly lower $(P<0.05)$ ALT activity was found in group T2 in comparison with the control female rats. Except for group T2, significant $(P<0.05)$ differences were found also for ALP activity.

\section{Discussion}

Bee pollen is an interesting feed additive rich in many nutrients and biologically active substances (Fatrcová-Šramková et al. 2016). Laboratory rats are useful animals for feeding trials for their very good reproductive ability and relative low feeding costs (Larsen et al. 1991). In this paper the effects of rapeseed bee pollen addition on growth intensity, biochemical energy, protein and enzymatic profile of Wistar rats were analysed. We confirmed the positive and stimulating effect of this phytogenic additive on the body 
weight and feed consumption as previously reported by Xie et al. (1994), Steiner (2006), and Bíro et al. (2010). Zdarilova et al. (2008) analysed the effect of different phytogenic additives rich in plant alkaloids on laboratory rats for 90 days. These authors found a nonsignificant negative effect on the final body weight of male rats, a tendency for the highest growth intensity was found in the control group without additive supplementation. This negative effect was described as an effect of alkaloids, which can work as an agent of growth depression. Similar results were also published by Stanek et al. (2015).

A growth-stimulating effect of bee pollen in an experiment with laboratory rats was reported by Selmanoglu et al. (2009). The same effect of bee pollen was found by Attia et al. (2011a) in an experiment with rabbit bucks. The authors found a tendency of the highest body weight gain after addition of $200 \mathrm{mg}$ of bee pollen per $\mathrm{kg}$ of body weight (twice per week). Attia et al. (2011a) also found a tendency for the lowest feed intake and feed conversion ratio in the experimental groups, and a tendency for the highest feed intake and feed conversion ratio in the control group. A similar effect of bee pollen was published following an experiment with doe rabbits (Attia et al. 2011b).

Phytogenic feed additives can reduce the cholesterol concentration in blood serum of animals (Steiner 2006). Some studies (e.g., Zdarilova et al. 2008) reported that phytogenic additives can affect serum cholesterol concentration only minimally. However, in our experiment we found a higher cholesterol content as an effect of different rapeseed bee pollen intake in serum of both male and female rats. Different results were published also by Aritajat et al. (2008). The authors found a positive effect of different plant extracts on the female serum cholesterol content. The reference range of serum cholesterol concentration is between 1.2 and $2.4 \mathrm{mmol} \cdot \mathrm{l}^{-1}$ (During et al. 2000). In case of TRG concentration, we found a tendency $(P>0.05)$ for lower TRG content with increasing bee pollen intake. Similar results were reported by Shirwaikar et al. (2005). The TRG serum content in male rats is affected mainly by age (Lukačínová et al. 2011b).

In our experiment, a non-significant $(P>0.05)$ effect of dietary bee pollen on serum glucose content was found. Lukačínová et al. (2011a) reported that glucose serum content is relatively stable in laboratory rats and affected mainly by age with an increasing tendency throughout life. Except for the control group, our results of glucose serum concentration were lower in comparison to the results of Lukačínová et al. (2008; 2011a). In this paper the highest $(P>0.05)$ serum total protein content in male rats was measured in the T2 group. Different results were published by Zdarilova et al. (2008). The dietary intake of rapeseed bee pollen affected the total protein serum content of female rats. Significant $(P<0.05)$ differences were found between the control group and group $\mathrm{T} 3$ of female rats. These results are in contrast with results reported by Zdarilova et al. (2008), who found a tendency for lower serum total protein content as an effect of increasing phytogenic additives intake in rats. Similar tendency was reported by Capcarová and Kolesárová (2010) also in the total creatinine and urea content with the addition of a phytogenic additive (Rhus coriaria $\mathrm{L}$.)

Zdarilová et al. (2008) reported that different phytogenic feed additives did not affect the enzymatic activity of rats' blood serum. However, higher AST activity, with the same tendency as in our experiment, was published by Capcarová and Kolesárová (2010). A tendency for higher ALP activity as an effect of dietary phytogenic additive intake was published by Capcarová and Kolesárová (2010) in an experiment with rabbits. Rapeseed bee pollen may be used as an animal feed additive for its positive effect on the body weight gain and nutrient utilisation.

\section{Acknowledgements}

This study was supported by Scientific Grant Agency of the Ministry of Education, Science, Research and Sport of the Slovak republic and Slovak Academy of Sciences (project No. 1/0723/15). 


\section{References}

Aritajat S, Saenphet K, Thaworn V, Wutteeraphol S 2008: Effects of selected herbal extracts on blood chemistry profiles in rats. Southeast Asian J Trop Med Pub Health 39: 78-81

Attia YA, Al-Hanoun A, Bovera F 2011a: Effect of different levels of bee pollen on performance and blood profile of New Zealand White bucks and growth performance of their offspring during summer and winter months. J Anim Physiol Nutr 95: 17-26

Attia YA, Al-Hanoun A, Tag El-Din AE, Bovera F, Shewika YE 2011b: Effect of bee pollen levels on productive, reproductive and blood traits of NZW rabbits. J Anim Physiol Nutr 95: 294-303

Bíro D, Gálik B, Juráček M, Šimko, M, Toman R 2010: Bee pollen in animal nutrition. In Brovarskyi V et al (Eds): Bee Pollen. FOP IS Maidachenko, Kijev, pp. 275-281

Capcarová M, Kolesárová A 2010: Beneficial Substances Affecting Internal Milieu of Animals. Slovak University of Agriculture, Nitra, $73 \mathrm{p}$

Carpes SJ, Mourao GB, Masson ML 2009: Chemical composition and free radicals scavenging activity of Apis mellifera bee pollen from Southern Brazil. Braz J Food Technol 12: 220-229

During A, Combe N, Mazette S, Entressangles S 2000: Effects on cholesterol balance and LDL cholesterol in the rat of a soft-ripened cheese containing vegetable oils. J Am Coll Nutr 19: 458-466

Fatrcová-Šramková K, Nôžková J, Máriássyová M, Kačániová M 2015: Biologically active antimicrobial and antioxidant substances in the Helianthus annus L. bee pollen. J Environ Sci Health 50: 176-181

Karásková K, Suchý P, Straková E 2015: Current use of phytogenic feed additives in animal nutrition - a Review. Czech J Anim Sci 60: 521-530

Kňazovická V, Kačániová M, Miluchová M, Gábor M, Dovičičová M, Melich M, Trakovická A 2011: Honey and Microorganisms: Monitoring of Microorganisms in Slovak Honey by Molecular-Biological Methods in Relation to Physico-Chemical Properties. LAP Lampert Academic Press, Saarbrücken, 192 p.

Larsen T, Ostergard K, Hansen I, Knudsen KEB, Eggum BO 1991: Daily food intake and digestibility in rats. Brit J Nutr 65: 29-35

Lukačínová A, Mojžiš J, Beňačka R, Rácz O, Ništiar F 2008: Structure-activity relationships of preventive effects of flavonoids in alloxan-induced diabetes mellitus in rats. J Anim Feed Sci 17: 411-421

Lukačínová A, Nováková J, Sedláková E, Lovásová E, Dombrovský P, Ništiar F 2011a: Reference values in male rats Wistar: $2^{\text {nd }}$ selected parameters of saccharides metabolism. In Fatrcová-Šramková K, Kubicová P (Eds): Nutrition and Health 2011. Slovak University of Agriculture, Nitra, pp. 324-331

Lukačínová A, Nováková J, Rácz O, Ništiar F 2011b: Reference Values in Male Rats Wistar: $3^{\text {rd }}$ Selected Parameters of Lipids Metabolism. In Fatrcová-Šramková K, Kubicová P (Eds): Nutrition and Health 2011. Slovak University of Agriculture, pp. 332-339

Selmanoglu G, Hayretdag S, Kolankaya D, Tuylu AO, Sorkun K 2009: The effect of pollen on some reproductive parameters of male rats. Pestic Phytomed 24: 59-63

Shirwaikar A, Rajindren K, Punitha ISR 2005: Antihyperglycemic activity of the aqueous stem extract of Coscinium fenestratrum in non insulin dependent diabetic rats. Pharm Biol 43: 707-712

Stanek M, Rotkiewicz T, Sobotka W, Bogusz J, Otrocka-Domagała I, Rotkiewicz A 2015: The effect of alkaloids present in blue lupine (Lupinus angustifolius) seeds on the growth rate, selected biochemical blood indicators and histopathological changes in the liver of rats. Acta Vet Brno 84: 55-62

Steiner T 2006: Managing Gut Health: Natural Growth Promoters as a Key to Animal Performance. Nottingham University Press, Nottingham, 98 p.

Šarič A, Balog T, Sobočanec S, Kušic B, Šverko V, Rusak G, Likic S, Bubalo D, Pinto B, Reali D, Marotti T 2009: Antioxidant effects of flavonoid from Croatian Cystus incanus L. rich bee pollen. Food Chem Toxicol 47: 547-554

Xie Y, Wan B, Li W 1994: Effect of bee pollen on maternal nutrition and fetal growth. J West China 25: 434-437

Zdarilova A, Vrublova E, Vostalova J, Klejdus B, Stejskal D, Proskova J, Kosina P, Svobodova A, Vecera R, Hrbac J, Cernochova, D, Vicar J, Ulrichova J, Simanek V 2008: Natural feed additive of Macleaya corbata: Safety assessment in rats a 90-day feeding experiment. Food Chem Toxicol 46: 3721-3726

Zuo J, Xu S 2003: Study and application of bee pollen as feed additive. Feed Review 11: 33-35 